\title{
ANTINKSČIU KRIZĖ: PATOLOGIJOS APŽVALGA IR GYDYMO BEI PREVENCIJOS GALIMYBĖS
}

\author{
Martynas Judickas \\ Lietuvos sveikatos moksly universiteto ligonine, Kauno klinikos, Vaiku ligu klinika
}

Raktažodžiai: antinksčių krizè, antinksčių nepakankamumas, hidrokortizonas.

\section{Santrauka}

Antinksčių krizè - tai ūmi gyvybei pavojinga būklè, lemianti pacientų, kuriems patvirtintas antinksčių nepakankamumas, didesnị mirštamumą. Nepaisant didelès antinksčių nepakankamumo gydymo pažangos, antinksčių krizè vis dar išlieka viena iš pagrindinių šios grupès pacientų mirties priežasčių, nes jai būdingas sisteminis organizmo pažeidimas, nesant specifinių simptomų, todèl sunku diagnozuoti ir neretai pavèluojama gydyti. Šiuo Straipsniuyje plačiau bus aptartasiamas antinksčiu krizès aktualumas, ligai būdingąa klinika, gydymo bei prevencijos gairès.

Tyrimo tikslas - apžvelgti ir aptarti retos, tačiau gyvybei itin pavojingos būklès - antinksčių krizès epidemiologijos, diagnostikos bei gydymo naujoves. Atlikta naujausių prevencinių programų bei gydymo gairių, kurios leistų sumažinti šios klinikinès būklès atvejų skaičių ateityje, paieška mokslinèje literatūroje. Literatūros šaltinių paieška vykdyta anglų kalba PubMed, UpToDate, Medscape ir Cohrane medicinos duomenų bazèse. Naudoti raktiniai žodžiai ir jų deriniai: adrenal crisis, adrenal insufficiency, hydrocortisone, treatment guidelines for adrenal crisis, prevention of adrenal crisis syndrome. Atrinkti 24 viso teksto moksliniai straipsniai, atitikę tyrimo tikslą ir atlikta jų analizè. Tyrimo rezultatai parodè, kad pagrindinis šią patologiją išprovokuojantis veiksnys yra infekcija, tačiau antinksčių krizès priežastis gali būti operacija, trauma, gliukokortikoidų terapijos plano nesilaikymas ar itin sunkus fizinis stresas. Pirmoji pagalba, nustačius antinksčių krizę, apima: parenterinį hidrokortizono skyrimą, rehidrataciją ir elektrolitų homeostazès atkūrimą. Pagrindinè prevencijos priemoné - pacientų edukacija. Išvados: 1) pirmo pasirinkimo vaistas gydyti antinksčių krizę yra hidrokortizonas; 2) pirmos kartos ir ilgo veikimo gliukokortikoidai prednizolonas ir deksametazonas nerekomenduojami, išskyrus atvejus, kai hidrokortizonu nepasiekiama efektyvaus gydymo; 3 ) laiku pradètas adekvatus gretutinių ligų, tokių kaip vėžys, autoimuniniai susirgimai, antinksčių nepakankamumas bei infekcijos, gydymas gali sumažinti antinksčių krizès atvejų skaičių; 4) sergantieji Adisono liga, reguliariai naudojantys specialius klausimynus savo būklei ịvertinti, gali reikšmingai sumažinti antinksčių krizès riziką.

\section{İvadas}

Steroidinių hormonų sintezès ir sekrecijos trūkumas sietinas su ženkliai didesniu sergamumu ir mirštamumu. Antinksčių žieveje sekretuojami trijų klasių hormonai, panaudojant jų prekursorių cholesterolį: mineralkortikoidai, gliukokortikoidai (GKK) ir lytiniai hormonai. GKK (kortizolis ir kortikosteronas) sekretuojami pluoštinès srities, kaip atsakas veikiant adrenokortikotropiniam hormonui (AKTH) ir yra plataus veikimo spektro per gliukokortikoidų receptorius. Pirminis antinksčių nepakankamumas (PAN) pasireiškia dẻl pažeidimo antinksčių žieveje. Dažniausios to priežastys: autoimuninis pažeidimas, infekcija ar igimta antinksčiu patologija [1]. Antrinis antinksčių nepakankamumas (AAN) sukeliamas esant pažeidimui pogumburio-hipofizès-antinksčiu (PHA) ašyje, kai antinksčiai nepakankamai stimuliuojami dèl neadekvačios AKTH sintezès ar sekrecijos. Dažniausia priežastis - hipofizès ligos, navikai ar chirurginis gydymas [2]. Ilgalaikis egzogeninių GKK vartojimas gali sukelti tretinį antinksčiu nepakankamumą [3]. Tradicinis antinksčių nepakankamumo gydymas - visą gyvenimą tęsiama pakaitinė GKK terapija. Gydymui itin svarbi gera diferencine PAN ir AAN diagnostika, nes PAN atveju yra visų antinksčiu žievès sekretuojamų hormonų trūkumas, o AAN atveju - pakaitinè aldosterono terapija nebūtina.

Tyrimo tikslas - apžvelgti ir aptarti retos, itin pavojingos gyvybei būklès - antinksčių krizès epidemiologijos, diagnostikos bei gydymo naujoves. 


\section{Tyrimo medžiaga ir metodai}

Literatūros šaltinių paieška vykdyta anglų kalba $\mathrm{Pu}-$ bMed, UpToDate, Medscape ir Cohrane medicinos duomenu bazèse. Ieškota klinikinių tyrimų ar jų apžvalgų, naujausių prevencinių programų bei gydymo gairių, kurių taikymas padètų sumažinti nagrinėjamos klinikinès būklès atvejų skaičių. Naudoti raktiniai žodžiai ir jų deriniai: adrenal crisis, adrenal insufficiency, hydrocortisone, treatment guidelines for adrenal crisis, prevention of adrenal crisis syndrome. Atrinkti ir išanalizuoti 24 viso teksto moksliniai straipsniai, atitikę tyrimo tikslą.

\section{Rezultatai ir jų aptarimas}

Antinksčių krizės epidemiologija. Remiantis klinikiniais tyrimais, manoma, jog antinksčių krizès dažnis didejja su pacientų amžiumi. Vienoje klinikinèje studijoje nustatyta, kad hospitalizacijos dèl šios patologijos skaičius gali siekti 24,3/1000000 sergančiujų inkstų nepakankamumu per metus, 60-69 metų amžiaus grupejje [4]. Antinksčių krizė dažnesné pacientams, turintiems gretutinių ligų, tokių kaip kaip I ir II tipo cukrinis diabetas (CD), astma ir kiaušidžių nepakankamumas [4].

Etiologija ir rizikos veiksniai. Antinksčių krizė gali išsivystyti ịvairiose klinikinèse situacijose. Tai gali būti pirmasis simptomas pacientams, kuriems prieš tai nebuvo nustatyta AN, arba pasireikšti kartu su infekcija ar kita ümia patologija ilgą laiką vartojantiems pakaitinę GKK terapiją [5]. Sergančiujų pirminiu antinksčių nepakankamumu rizika patirti antinksčių krizę yra kur kas didesnè, nei sergant antriniu AN [6-7]. Viena priežasčių, lemiančių dažnesnę sergančiųjų PAN antinksčių krizę yra ta, jog sergantieji AAN vis dar turi išlikusią menką kortizolio sekreciją [8]. Sergantiems AAN ši patologija dažnai pasireiškia, staiga nutraukus GKK vartojimą, įskaitant ir inhaliuojamus GKK [9]. Remiantis retrospektyvinèmis ir prospektyvinėmis studijomis, pačiomis dažniausiomis antinksčių krizès priežastimis laikomos gastroenteritas (35-45\%) ir karščiavimas (17-24\%) [9-10]. Infekcijos, ypač gastrointestinalinès, laikomos vienu iš dažniausiai antinksčių krizę predisponuojančių veiksnių (N). Pacientų, anksčiau patyrusių antinksčių krizę, šios patologijos recidyvo rizika padidèja tris kartus.

Klinika ir laboratoriniai tyrimai. Pagrindiniai antinksčių krizès simptomai yra hipotenzija ir hipovolemija. Dažnai ši patologija gali pasireikšti tik tokiais nespecifiniais simptomais kaip anoreksija, pykinimas, dispepsija, pilvo skausmai, silpnumas, letargija, karščiavimas ar sutrikusi sąmonè [11-13]. Dèl klastingos antinksčių krizès pradžios, ji neretai diagnozuojama pavèluotai. Viename tyrime nustatyta, jog 66,9 proc. pacientų 90 dienų laikotarpiu lankèsi ligoninèje, prieš pasireiškiant antinksčių krizei $[14,20]$.
Esant PAN, stebimas elektrolitų disbalansas: hiponatremija ir hiperkalemija, dèl mineralkortikoidų trūkumo [3].

Gydymas. Visose antinksčių krizès gydymo gairèse pabrèžiama ankstyvos gydymo pradžios svarba, nes, įtariant šią patologiją, pagrindinis galimos klinikinès baigties veiksnys yra laikas [15-17]. Dèl diagnostinių tyrimų neturètų būti pavèlinta gydymo pradžia. Kraujo tyrimai kortizolio ir AKTH koncentracijoms nustatyti turètų būti paimti kuo anksčiau. Gydymas pradedamas, nelaukiant tyrimų atsakymų. Tiek vaikams, tiek suaugusiesiems, remiantis prancūzų endokrinologų konsensuso $2018 \mathrm{~m}$. rekomendacijomis, pirmo pasirinkimo vaistas turi būti hidrokortizonas [22]. Pirmoji pagalba antinksčių krizés metu - parenterinis hidrokortizono $100 \mathrm{mg}$ boliusas intravenine (i/v) injekcija arba intramuskuliariai (i/m). Po boliuso, dar $200 \mathrm{mg}$ hidrokortizono per 24 val., paskiriant nuolatinę i/v infuziją ar skiriant hormono kas 6 val. po $50 \mathrm{mg} \mathrm{i} / \mathrm{v}$ arba i/m [18-19]. Nuolatinè hidrokortizono infuzija padeda palaikyti pastovią kortizolio koncentraciją kraujo serume [19]. Kai kurie autoriai siūlo naudoti ir didesnes $(100 \mathrm{mg} / 6 \mathrm{val})$ hidrokortizono koncentracijas [3]. Ne viena studija patvirtina, jog 50 $\mathrm{mg} / 6$ val. ar $200 \mathrm{mg} / 24 \mathrm{val}$. yra pakankama dozuote palaikyti adekvačią kortizolio koncentraciją [3]. Suaugusiems pacientams pirmos kartos ilgo veikimo GKK (prednizolonas, deksametazonas) neturètų būti skiriami, išskyrus atvejus, kai nepasiekiama norimo efekto hidrokortizonu dèl farmakokinetinių priežasčių [22]. Vaikams prednizolonas ar deksametazonas gali būti skiriamas tik su specialisto rekomendacijomis [22]. Skubią rehidrataciją patariama pradèti izotoniniu tirpalu, skiriant 1 litrą $\mathrm{NaCl}$ 0,9\% dideliu greičiu per pirmają valandą, vèliau palaikant pastovią infuziją, priklausomai nuo paciento būklès. İprastai skiriama apie 4-6 1 per 24 val., vykdant gyvybinių rodiklių stebėseną, siekiant išvengti širdies perkrovos ar antinksčių nepakankamumo [23]. Ittarus antinksčių krizę, pacientus patariama gydyti intensyviosios terapijos skyriuje, kur galima užtikrinti tinkamą jų būklès stebėseną, reguliariai vertinti kraujo elektrolitų balansą, taip išvengiant per greitos hiponatremijos korekcijos [3]. Išleidus pacientą iš stacionaro, gydymas tęsiamas visą likusi gyvenimą, išskyrus tokias išimtis, kaip pastovaus gydymo GKK nutraukimas ar pacientų atsigavimas po operacijų dėl hiperkortizolizmo [22].

Suaugusiems pacientams pirmos kartos ilgo veikimo GKK (prednizolonas, deksametazonas) neturètų būti skiriami, išskyrus atvejus, kai hidrokortizonu nepasiekiama norimo efekto dèl farmakokinetinių priežasčių. Vaikams prednizolonas ar deksametazonas gali būti skiriamas tik su specialisto rekomendacijomis.

Prevencijos ir prognozès strategijos. Terapinių pacientų edukacija laikoma nemedikamentinio gydymo dalimi, kuri 
yra itin efektyvi pacientams, sergantiems antinksčių nepakankamumu [21]. Švietimo programų tikslas - kelti pacientu kompetenciją, kuri juos ịgalintų savarankiškai ir efektyviai apsisaugoti nuo gyvybei pavojingų rizikos veiksnių, išprovokuojančių antinksčių krizę. Tyrime, kuriame buvo surinkti duomenys apie 504 pacientus, kuriems patvirtinta antinksčiu krizè, 68,5 proc. šių pacientų turèjo gretutinių ligų (piktybiniai navikai, autoimuniniai susirgimai bei antinksčiu nepakankamumas), kurios ir išprovokavo AAN [14]. Antinksčių krizès atvejų skaičių būtų galima sumažinti, jei žmonès naudotųsi prevencinemis programomis ir laiku kreiptųsi ị gydytojus. Gerai kontroliuojamų ligų fone būtų išvengta tokios komplikacijos, kaip antinksčiu krizè. Klinikiniais tyrimais įrodyta, jog pacientai, kurie naudoja pakaitinę GKK terapiją ir lanko edukacines programas, geriau žino kaip elgtis tam tikrose ligos paūmèjimo situacijose [24]. Adisono ligai specifinis gyvenimo kokybès klausimynas (AddiQoL) buvo sukurtas norint išsiaiškinti, ar jo rezultatai padètų identifikuoti pacientus, didejjant antinksčių krizès rizikai [23]. Prospektyvinio tyrimo duomenimis, kuriame dalyvavo 110 pacientų su patvirtinta Adisono liga, pastebèta, kad pacientų, kuriems išsivystė antinksčių krizè, AddiQoL klausimyno rezultatai 10 mèn. laikotarpyje buvo labiau svyruojantys [24]. Antinksčiu krizès pasireiškimas tyrimo metu siekè $10,9 / 100$ pacientu. Statistiškai reikšmingai labiau svyruojantys AddiQoL klausimyno rezultatai toje pacientų grupeje, kuriems ši komplikacija išsivyste, siejami su tuo, jog prieškrizinès stadijos metu ligoniams reikejo padidinti hidrokortizono dozuotę, dèl kurios ir pablogejo gyvenimo kokybė [23-24]. Tokie tyrimai kaip šis ịrodo, jog pacientai, galedami reguliariai ịvertinti savo sveikatos ar gyvenimo kokybę specialiais klausimynais, turètų veiksmingą priemonę, kurios naudojimas padètų laiku kreiptis i gydytojus ir išvengti sunkių komplikacijų.

\section{Išvados}

1. Pirmo pasirinkimo vaistas gydyti antinksčių krizę visų amžiaus grupių pacientams yra hidrokortizonas.

2. Pirmos kartos ir ilgo veikimo gliukokortikoidai prednizolonas ir deksametazonas nerekomenduojami, išskyrus atvejus, kai hidrokortizonu nepasiekiama efektyvaus gydymo.

3. Laiku pradètas adekvatus gretutinių ligų, tokių kaip vèžys, autoimuniai susirgimai, antinksčių nepakankamumas bei infekcijos, gydymas, gali sumažinti tokios klinikinès komplikacijos kaip antinksčiu krizė atvejų skaičių.

4. Pacientai, sergantys Adisono liga, reguliariai naudodami specialius klausimynus savo būklei ịvertinti, gali reikšmingai sumažinti antinksčių krizès riziką.

\section{Literatūra}

1. Bancos I, Hahner S, Tomlinson J, et al. Diagnosis and management of adrenal insufficiency. Lancet Diabetes Endocrinol
2015; 3: 216-226.

https://doi.org/10.1016/S2213-8587(14)70142-1

2. Grossman AB. Clinical Review\#: the diagnosis and management of central hypoadrenalism. J Clin Endocrinol Metab 2010; 95 : 4855-4863.

https://doi.org/10.1210/jc.2010-0982

3. Soiza RL, Donaldson AIC, Myint PK. Vaccine against arteriosclerosis: an update. Ther Adv Vaccines 2018;9(6):259-61.

4. Chabre O, Goichot B, Zenaty D, Bertherat J. SFE/SFEDP adrenalinsufficiency consensus. Group 1. Epidemiology of primary and secondaryadrenal insufficiency: prevalence and incidence, acute adrenal insufficiency, long-term morbidity and mortality. Ann Endocrinol 2017;78:490-4.

https://doi.org/10.1016/j.ando.2017.10.010

5. Rushworth RL and Torpy DJ. A descriptive study of adrenal crises in adults with adrenal insufficiency: increased risk with age and in those with bacterial infections. BMC Endocr Disord 2014; 14: 79.

https://doi.org/10.1186/1472-6823-14-79

6. Chanson P, Guignat L, Goichot B, Chabre O, Samara-Boustani $\mathrm{D}$, Rey-naud R, et al. SFE/SFEDP adrenal insufficiency consensus. Group 2:Adrenal insufficiency: screening methods and confirmation of diagnosis. Ann Endocrinol 2017;78:495-511. https://doi.org/10.1016/j.ando.2017.10.005

7. Prete A, Yan Q, Al-Tarrah K, et al. The cortisol stress response induced by surgery: a systematic review and meta-analysis. Clin Endocrinol (Oxf) 2018; 89:554-567.

https://doi.org/10.1111/cen.13820

8. Burger-Stritt S, Kardonski P, Pulzer A, et al. Management of adrenal emergencies in educated patients with adrenal insufficiency-A prospective study. Clin Endocrinol (Oxf) 2018; 89: 22-29.

https://doi.org/10.1111/cen.13608

9. Todd GR, Acerini CL, Ross-Russell R, et al. Survey of adrenal crisis associated with inhaled corticosteroids in the United Kingdom. Arch Dis Child 2002; 87: 457-461.

https://doi.org/10.1136/adc.87.6.457

10. Iqbal MS, Hardman J. Addisonian crisis secondary to bilateral adrenal metastases in rectal carcinoma: report of a rare case and literature review. J Gastrointest Cancer 2013;44: 225-227. https://doi.org/10.1007/s12029-012-9426-x

11. Castinetti F, Guignat L, Bouvattier C, Samara-Boustani D, Reznik Y. SFE/SFEDP adrenal insufficiency consensus. Group 4: Replacement therapyfor adrenal insufficiency. Ann Endocrinol 2017;78:525-34.

https://doi.org/10.1016/j.ando.2017.10.007

12. Proust-Lemoine E, Reynaud R, Delemer B, Tabarin A, Samara-Boustani D. SFE/SFEDP adrenal insufficiency consensus. Group 3: Strategies for identifying the cause of adrenal insufficiency: diagnostic algorithms. Ann Endocrinol 2017;78:512-24. https://doi.org/10.1016/j.ando.2017.10.006 
13. Trainer H, Hulse P, Higham CE, et al. Hyponatraemia secondary to nivolumab-induced primary adrenal failure. Endocrinol Diabetes Metab Case Rep 2016;2016:16-0108.

https://doi.org/10.1530/EDM-16-0108

14. Iwasaku M, Shinzawa M, Tanaka S, et al. Clinical characteristics of adrenal crisis in adult population with and without predisposing chronic adrenal insufficiency: a retrospective cohort study. BMC Endocr Disord 2017;17:58.

https://doi.org/10.1186/s12902-017-0208-0

15. Bornstein SR, Allolio B, Arlt W, et al. Diagnosis and treatment of primary adrenal insufficiency: An Endocrine Society Clinical Practice Guideline. J Clin Endocrinol Metab 2016;101:364-389. https://doi.org/10.1210/jc.2015-1710

16. Arlt W, Society for Endocrinology Clinical Committee. Society for Endocrinology Endocrine Emergency Guidance: emergency management of acute adrenal insufficiency (adrenal crisis) in adult patients. Endocr Connect 2016; 5: G1-G3.

https://doi.org/10.1530/EC-16-0054

17. Higham CE, Olsson-Brown A, Carroll P, et al. Society for Endocrinology Endocrine Emergency Guidance: acute management of the endocrine complications of checkpoint inhibitor therapy. Endocr Connect 2018; 7: G1-G7.

https://doi.org/10.1530/EC-18-0068

18. Gagliardi L, Nenke MA, Thynne TR, et al. Continuous subcutaneous hydrocortisone infusion therapy in Addison's disease: a randomized, placebo-controlled clinical trial. J Clin Endocrinol Metab 2014; 99: 4149-4157. https://doi.org/10.1210/jc.2014-2433

19. Lagger G, Pataky Z and Golay A. Efficacy of therapeutic patient education in chronic diseases and obesity. Patient Educ Couns 2010; 79: 283-286.

https://doi.org/10.1016/j.pec.2010.03.015

20. Cortet C, Barat P, Zenaty D, Guignat L, Chanson P. SFE/ SFEDP adrenalinsufficiency consensus. Group 5: Acute adrenal insufficiency in adults andpediatric patients. Ann Endocrinol 2017;78:535-43.

https://doi.org/10.1016/j.ando.2017.10.008

21. Vidmar AP, Weber JF, Monzavi R, et al. Improved medical-alert ID ownership and utilization in youth with congenital adrenal hyperplasia following a parent educational intervention. J Pediatr Endocrinol Metab 2018; 31: 213-219.

https://doi.org/10.1515/jpem-2017-0435
22. Reznik Y, Barat P, Bertherat J, Bouvattier C, Castinetti F, Chabre O, et al. SFE/SFEDP adrenal insufficiency French consensus: Introduction and handbook. Ann Endocrinol (Paris) 2018;79(1):1-22.

https://doi.org/10.1016/j.ando.2017.12.001

23. Oksnes M, Bensing S, Hulting AL, et al. Quality of life in European patients with Addison's disease: validity of the disease-specific questionnaire AddiQoL. J Clin Endocrinol Metab 2012; 97: 568-576.

https://doi.org/10.1210/jc.2011-1901

24. Meyer G, Koch M, Herrmann E, et al. Longitudinal AddiQoL scores may identify higher risk for adrenal crises in Addison's disease. Endocrine 2018;60:355-361.

https://doi.org/10.1007/s12020-017-1513-0

\section{ADRENAL CRISIS: REVIEW ON TREATMENT AND PREVENTION POSSIBILITIES M. Judickas}

Keywords: adrenal crisis, adrenal insufficiency, hydrocortisone. Summary

Adrenal crisis a life-threatening emergency that causes increased mortality in patients with adrenal insufficiency. During adrenal crisis patients present systemically unwell and have nonspecific symptoms that often leads to misdiagnosis or delayed treatment. The major precipitating factor is enfection. However operation, trauma, discontinuing glucocorticoid therapy and extreme physical stress may also cause adrenal crisis. First aid includes prompt administration of parenteral glucocorticoids, restoration of electrolyte homeostasis and rehydration. The main tool for prevention is patient education. Every patient should be trained on how to dose and administer parenteral glucocorticoids. Despite great progress in dealing with adrenal insufficiency, adrenal crisis remains to be one of the main mortality causes. In this article we will overview adrenal crisis relevance, typical clinical presentation, treatment and prevention guidelines.

Correspondence to: martynas.judickas@gmail.com

Gauta 2021-05-18 